\title{
A FAMÍLIA OCUPACIONAL "ARQUIVISTAS E MUSEÓLOGOS”: POSICIONAMENTO NA CLASSIFICAÇÃO BRASILEIRA DE OCUPAÇÕES E PERFIL DE EMPREGO
}

\author{
THE OCCUPATIONAL FAMILY "ARCHIVISTS AND MUSEOLOGISTS": \\ POSITIONING IN THE BRAZILIAN OCCUPATIONS CLASSIFICATION AND \\ EMPLOYMENT PROFILE
}

\author{
T. S. ALVES ${ }^{1, *}$
}

1 Universidade Federal de Minas Gerais, Programa de Pós-Graduação em Ciência da Informação, Brasil

\author{
ARTICLE INFO \\ Article history: \\ Received 2018-07-02 \\ Accepted 2018-08-17 \\ Available online 2018-08-31 \\ ${ }^{*}$ Autor correspondente: \\ E-mail: thialves@yahoo.com.br
}

Palavras-chave: Classificação Brasileira de Ocupações. Arquivistas. Museólogos. Relação Anual de Informações

Sociais.

Keywords: Brazilian Occupation Classification. Archivists. Museologists. Social Information Annual Report.

RESUMO. Os Arquivistas e os Museólogos estão reunidos na Família ocupacional "Arquivistas e Museólogos", na Classificação Brasileira de Ocupações. A fim de contribuir para uma reflexão crítica sobre o posicionamento de tais profissionais neste instrumento classificatório, a dissertação "A Família ocupacional 'Arquivistas e Museólogos': posicionamento na Classificação Brasileira de Ocupações e perfil de emprego", defendida em 2016, no Programa de Pós-Graduação em Ciência da Informação da Universidade Federal de Minas Gerais, buscou responder às seguintes questões: por que o posicionamento dos Arquivistas e dos Museólogos, na Classificação Brasileira de Ocupações, se dá em uma mesma Família ocupacional? Quem são e onde estão empregados os "Arquivistas e Museólogos"? Os objetivos específicos desta pesquisa foram: apresentar o posicionamento dos Arquivistas e dos Museólogos na Classificação Brasileira de Ocupações; explicar o motivo pelo qual estes profissionais formam uma única Família ocupacional; caracterizar o perfil de emprego formal dos "Arquivistas e Museólogos", a partir dos dados estatísticos da Relação Anual de Informações Sociais. A fundamentação desta pesquisa foi feita através dos aportes teóricos da Sociologia das Profissões; da trajetória sócio-histórica dos Arquivistas e dos Museólogos; das interfaces entre a Arquivologia, a Museologia e áreas interdisciplinares; e dos estudos sobre o mercado de trabalho dos Arquivistas, dos Museólogos e da Família ocupacional "Arquivistas e Museólogos". A abordagem metodológica utilizada foi qualitativa e quantitativa; o nível de interpretação dos objetivos foi do tipo descritivo e explicativo; e as técnicas de pesquisa utilizadas foram pesquisa documental e pesquisa bibliográfica. O tema foi 
relevante por contribuir com apontamentos para uma possível atualização e revisão de parte do documento da Classificação Brasileira de Ocupações; por serem poucas as pesquisas sobre esta Família ocupacional e por inovar ao utilizar a Relação Anual de Informações Sociais para caracterizar os "Arquivistas e Museólogos". Os resultados desta pesquisa apontam que: "Arquivistas e Museólogos" pertencem à mesma Família ocupacional por motivos pragmáticos - não houve consistência teórica e metodológica para esta junção -, por inexpressividade numérica e pelo uso, mesmo que adaptado, da Classificação Internacional Uniforme de Ocupações, de 1988, como referência para a elaboração da Classificação Brasileira de Ocupações; existem interfaces entre a Arquivologia e a Museologia, mas os profissionais destas áreas possuem distintos objetos de trabalho e atribuições específicas no mercado; para ser uma ferramenta útil, as informações da Classificação Brasileira de Ocupações precisam estar atualizadas com a realidade de trabalho destes profissionais; esta pesquisa poderá orientar eventuais alterações em futuras oportunidades de revisão da Classificação Brasileira de Ocupações; a partir dos dados da Relação Anual de Informações Sociais, pode-se inferir certo perfil de quem são e onde estão empregados formalmente os 2.652 "Arquivistas e Museólogos"; os dados agregados pouco revelam sobre o perfil de emprego de cada profissional e dificulta a viabilização de propostas de políticas públicas de formação e emprego para Arquivistas e Museólogos, por isso, é latente a necessidade de melhor conhecer o mercado de trabalho destes profissionais de forma desagrupada; a comprovação de algumas hipóteses sobre o trabalho dos Arquivistas e dos Museólogos e uma completa observação da realidade só poderão ser feitas com a desvinculação das duas profissões e/ou dos dados estatísticos correspondentes.

ABSTRACT. Archivists and Museologists are gathered on the "Archivists and Museologists" Occupational family, in the Brazilian Occupations Classification. In order to contribute to a critical reflection about these professionals positioning, in this classificatory instrument, the dissertation "The Occupational family 'Archivists and Museologists': positioning in the Brazilian Classification of Occupations and employment profile", defended in 2016, in the Post-Graduation Program in Information Science of the Federal University of Minas Gerais, aimed to answer the following questions: why the Archivists and Museologists positioning is inside the same Occupational family? Who are the "Archivists and Museologists" and where are they working? This research specific objectives were: present the Archivists and Museologists positioning in the Brazilian Occupations Classification; explain the reason why these professionals are linked within a sole Occupational family; characterize the formal job profile of the "Archivists and Museologists" from statistic data displayed on the Social Information Annual Report. This research was based on theoretical aports from the Professions Sociology; from Archivists and Museologists socio-historical trajectory; from interfaces between Archivology, Museology and interdisciplinary areas; from the conceptualization of Brazilian Occupations Classification; from studies about the labor market of the Archivists, the Museologists and the "Archivists and Museologists". The methodological approach was qualitative and quantitative; the interpretational level of objectives was descriptive and explicative; and documental and bibliographical researches were the used techniques. This is a relevant theme, for it contributes with notes that can be used on a possible revision and updating of the Brazilian Occupations Classification document; for there are only a few researches about this Occupational family and for innovating while using the Social Information Annual Report to characterize the "Archivists and Museologists". This research's results point to the following ideas: "Archivists and Museologists" belong to the same Occupational family for pragmatic reasons - there was not any theoretical and methodological consistency for this junction -, for numerical blankness and for the use, even though adapted, of the International Standard Classification of Occupations, from 1988, as a reference to elaborate the Brazilian Occupations Classification; there are interfaces between Archivology and Museology, but the area professionals work with different objects and get specific attributions; in order to be a useful tool, the Brazilian Occupations Classification informations must be updated according to the labor reality of those professionals; this research may guide any modifications through future revision opportunities of the Brazilian Occupations Classification; one can infer a certain profile of who and where are formally employed the 2.652 "Archivists and Museologists", based on the Social Information Annual Report data; the aggregated data do not reveal much about each professional job profile and obstruct public proposals and policies of Archivists and Museologists formation and employment, that is why the need of a better knowledge about the labor market of those professionals is latent and should be done in an ungrouped way; the evidencing of some hypothesis about the Archivists and Museologists job and a complete reality observation will only be done with the splitting of these two professions or/and of the corresponding statistical data. 


\section{Referência}

ALVES, Thiara dos Santos. A Família ocupacional "Arquivistas e Museólogos": posicionamento na Classificação Brasileira de Ocupações e perfil de emprego. Belo Horizonte, 2016. Dissertação (Mestrado em Ciência da Informação) - Escola de Ciência da Informação, Universidade Federal de Minas Gerais, 2016. Disponível em: $<$ http://www.bibliotecadigital.ufmg.br/dspace/handle/1843/BUBD-AE3HFE>. Acesso em: 08 jul. 2018. 